\title{
Hegemoni Amerika Serikat Terhadap Arah Kebijakan Arab Saudi dalam Konflik Yaman Pasca Arab Spring 2011-2017
}

\author{
Firmanda Taufiq \\ Konsentrasi Kajian Timur Tengah Program Studi Interdisciplinary Islamic Studies \\ Pascasarjana UIN Sunan Kalijaga Yogyakarta \\ email: firmandataufiq@gmail.com \\ Lalu Wahyu Putra Utama \\ Konsentrasi Kajian Timur Tengah Program Studi Interdisciplinary Islamic Studies \\ Pascasarjana UIN Sunan Kalijaga Yogyakarta \\ email: wahyuputrautama786@gmail.com
}

\section{ABSTRACT}

This article aims to analyze the hegemony of the United States against the direction of Saudi policy in the Yemeni conflict. Historically United States and Saudi Arabia have a close relationship since 1940's. The relationship is based on economic, political, military and security interests. With US support, Saudi Arabia has a major influence in the Middle East. The research question in this paper is what is the reason of Saudi's attack toward Yemen and what is the role of United States in this aggression. The theory used in this study is the theory of hegemony which is trying to explain how a country controlled other countries politically and economically. The study finds that Saudi Arabia's foreign policy toward Yemen is one of the effect of American hegemony.

Keywords: hegemony, United States, economy-politics, Saudi Arabia, Yemen 


\section{ABSTRAK}

Artikel ini bertujuan untuk menganalisa hegemoni Amerika Serikat agresi militer Arab Saudi terhadap Yaman. Secara historis Amerika Serikat dan Arab Saudi memiliki hubungan erat yang dimulai sejak tahun 1940-an. Hubungan tersebut didasarkan pada kepentingan ekonomi, politik, militer, dan keamanan. Dukungan Amerika Serikat terhadap Arab Saudi memiliki pengaruh besar terhadap negara-negara di Timur Tengah. Pertanyaan penelitian ini adalah apa alasan Arab Saudi dalam mengagresi Yaman dan bagaimana peran Amerika Serikat terhadap keputusan Arab Saudi tersebut. Teori yang dipakai dalam penelitian ini adalah teori hegemoni yang berusaha menjelaskan bagaimana suatu negara menguasai negara lain secara politik dan ekonomi. Temuan penelitian ini adalah kebijakan luar negeri Arab Saudi merupakan salah satu dampak hegemoni Amerika Serikat.

Kata kunci: hegemoni, Amerika Serikat, ekonomi-politik, Arab Saudi, Yaman

\section{Pendahuluan}

Kerajaan Arab Saudi berdiri sejak 1932 dan berada di bawah pimpinan keluarga Al-Saud. Secara historis salah satu negara teluk Tni menjadi tempat lahirnya agama Islam serta sebagai sumber ladang minyak melimpah dengan rata-rata produksi 10 juta barrel per hari. Sebagai negara yang memiliki sejarah penting dalam Dunia Islam dan sumber daya minyak terbesar di dunia menyebabkan Arab Saudi memiliki peran dan pengaruh besar di dunia. ${ }^{1}$ Akan tetapi, kebesaran posisi dan pengaruh tersebut tidak lepas dari hasil kerjasama kuat antara Amerika Serikat dengan pemerintahan Arab Saudi. Awal kedekatan Amerika dengan Arab Saudi secara politis dapat dilacak pada saat Amerika mengakui Raja Abdul Aziz Al Saud pada 1931, sebagai penguasa Hijaz dan Najd, setahun sebelum dia mendeklarasikan Kerajaan Saudi Arabia. Peningkatan hubungan antara kedua negara pada era 1930-an hingga 1945 terjadi seiring dengan kerjasama eksplorasi konsesi minyak yang dilakukan California Arabian Standar Oil Company (CASOC) kemudian dikenal dengan Arabian American Oil Company (ARAMCO). ${ }^{2}$ Maka, secara historis hubungan Amerika Serikat dan Arab Saudi telah ditandai dengan kerjasama minyak untuk keamanan (oil for security). Pada tahun 1943, President AS Franklin Roosevelt

1 Gause III , F. Gregory. 2014. "Saudi Arabia in The New Middle East". Council of Foreign Relation No. 63: 23.

2 Blanchard, Christopher M. CRS Report for Congress, Saudi Arabia: Background and U.S Relation. Melalui http://digital.library.unt.edu/ark:/67531/metadc462604/.pdf 
mengeluarkan pernyataan, "pembelaan terhadap Arab Saud adalah penting untuk pembelaan terhadap AS." Pertemuan kedua kepala negara pertama kali adalah pada Februari 1945, dimana President Roosevelt bertemu dengan Raja Abdul Aziz di kapal USS Quincy di Terusan Suez.

Pada pertengahan 1970-an, Arab Saudi sudah mampu mengendalikan harga minyak dunia dengan harga pantas serta mampu menurunkan harga minyak di pasaran secara cepat pada masa krisis. Ini adalah adalah salah satu keuntungan paling nyata yang diperoleh Amerika Serikat dari hubungan baik tersebut. ${ }^{3}$

Selama tahun 1960-an Amerika Serikat membantu Arab Saudi melindungi perbatasan negaranya melawan Soviet yang didukung Mesir. Kedua negara bekerjasama melawan pengaruh Iran selama perang Irak-Iran antara 1980 dan 1988. Bahkan bisa dikatakan selama Perang Dingin bergulir, Arab Saudi sebagai negara akses militer bagi Amerika Serikat. ${ }^{4}$

Hubungan antara Amerika Serikat dan Arab Saudi telah tumbuh dengan pesat disebabkan adanya berbagai kepentingan, terutama ekonomi dan keamanan. Amerika Serikat adalah aktor luar utama di kawasan Timur Tengah. Tujuan Amerika Serikat menyebarkan pengaruhnya melalui Arab Saudi adalah sebagai representasi suksesi ekonomi dunia dan sebagai mitra strategis kontra-terorisme yang menjadi masalah berkepanjangan di negara Timur Tengah.

Kesuksesan Arab Saudi dapat juga dikatakan kesuksesan politis Amerika Serikat di Timur Tengah. Bahkan, Arab Saudi sebagai pimpinan negara Teluk mampu menyatukan Yaman Utara dan Yaman Selatan. Yaman Utara atau Republik Arab Yaman (YAR) menerima bantuan dari Arab Saudi serta Yaman Selatan memperoleh pasokan senjata dari Uni Soviet. Kedua pimpinan Yaman Utara dan Selatan kemudian setuju untuk menarik pasukan dan menciptakan zona demilitarisasi yang memudahkan penyeberangan bagi warga masingmasing negara. Akhirnya pada tahun 1990, terbentuklah Republik Arab Yaman yang menyatukan kedua Yaman dengan Ali Abdullah Saleh menjadi presidennya. $^{5}$

3 Rachel Bronson. 2006. Ticker Than Oil: America's Uneasy Partnership with Saudi Arabia, (New York: Oxford University Press. (3)

$4 \quad$ Ibid.(4)

5 Syarif Ismail, Wadham College. "Unification in Yemen: Dynamics of Political 
Dengan dominasi politiknya serta kemampuan dalam memobilisasi kepentingan kelompok oposisi, Ali Abdullah Saleh ${ }^{6}$ berhasil menjadi Presiden Yaman selama 3 dekade. Selama itu pula, hubungan Saleh dengan Saudi berjalan stabil dan kooperatif; bahkan beberapa anggota keluarga kerajaan Arab Saudi terus menyalurkan dana miliaran dollar untuk mendanai kepentingan Ali Abdullan Saleh. ${ }^{7}$

Pada akhir 2010 Arab Spring mengguncang negara-negara Arab. Gelombang aksi-aksi demonstrasi di berbagai negara Timur Tengah mengakibatkan jatuhnya rezim-rezim otoriter yang telah lama berkuasa, seperti Presiden Zine al-Abidine Ben Ali di Tunisia dan Presiden Husni Mubarak di Mesir. Bahkan, pemimpin besar Libya, Muammar Khadaff, akhirnya tewas secara tragis setelah ditembak kepala dan kedua kakinya. ${ }^{8}$ Gelombang protes ini juga muncul secara masif di Yaman, yang memaksa Ali Abdullah Saleh mengundurkan diri lalu eksodus ke Arab Saudi. ${ }^{9}$ Pemerintahan Yaman ad interim kemudian terbentuk, dipimpin oleh Mansour Hadi. Namun gelombang demo masih berlanjut karena reformasi yang dihendaki rakyat masih belum terwujud. Mansour Hadi kemudian juga melarikan diri ke Saudi dan meminta bantuan dari pemerintah Saudi untuk menyelesaikan konflik di negaranya.

Sejak Maret 2015, Arab Saudi melakukan serangan udara ke Yaman, membombardir secara acak berbagai target di Yaman sehingga mengakibatkan jatuhnya puluhan ribu korban jiwa dan tiga juga orang

\footnotetext{
Integration 1978-2000, 19-20". Melalui <http://users.ox.ac.uk/metheses/ IsmailThesis.pdf $>$.
}

6 Selain mendapatkan dukungan dari kelompok Syiah Zaidiyah, Ali Abdullah Saleh secara politis mendapatkan dukungan penuh dari para pemimpin Sunni. Dengan demikian, selama menjabat sebagai kepala negara, General Congress Party mendominasi berkat kemampuannya merangkul kelompok mayoritas.

7 Al-Faqih, Abdullah. 2011. "The Yemen Upraising: Imperatives for Change and Potential Risk (ARI)". Melalui <https://www.files.ethz.ch/isn/ENGLISHANDSPANISH_ ARI58-2011_Al-faqih_Yemen_Uprising_Change_Risks.pdf.> [1/1/2017]

8 Sidik Jatmika. 2014. Pengantar Studi Kawasan Timur Tengah. Yogyakarta: Maharsa. (171)

9 Pada bulan April 2011, Dewan Kerjasama Teluk (Gulf Cooperation Council) pimpinan Arab Saudi dan didukung oleh Amerika Serikat menyarankan agar Ali Abdullah Saleh turun jabatan kepresidenan dan melakukan proses transisi. Negosiasi ini melibatkan Saleh, Ali Muhsin dan al-Ahmar. Kesepakatan ini bertujuan untuk melindungi dirinya dan aliansi politiknya di parlemen. Lihat. Mehran Kamrava (Editor), Beyond The Arab Spring: The Evolving Ruling Bergain in the Middle East, (New York: Oxford University Press, 2014).383. 
terpaksa menjadi pengungsi internal. ${ }^{10}$ Menteri Luar Negeri Arab Saudi, Adel al Jubeir menyatakan bahwa pejabat militer AS ada di 'ruang komando' dalam penyerangan ini. ${ }^{11}$ Dalam tulisan ini, penulis akan menelusuri lebih mendalam tentang peran Amerika Serikat terhadap keputusan Arab Saudi dalam menyerang kelompok Houthi Yaman.

\section{Landasan Teori}

Hegemoni dapat diartikan sebagai dominasi sebuah kelompok terhadap kelompok lainnya, dengan atau tanpa ancaman kekerasan sehingga ide-ide yang didiktekan oleh kelompok dominan terhadap kelompokyang didominasi diterima sebagai sesuatu yang wajar dan bersifat moral, intelektual serta budaya. Menurut Lukes, kekuatan setidaknya memiliki dua dimensi. Dimensi petama aliran yang disebut sebagai "plurasi" atau dalam bidang Hubungan Internasional disebut sebagai "neorealis" dimana memahami power sebagai suatu yang dapat dibuktikan serta dapat dikuantifikasikan. ${ }^{12}$ Aliran kedua fokus pada suatu tujuan untuk menetapkan suatu aturan main. Perpektif ini sering diasosiasikan dengan teori institusionalis liberal secara umum bertujuan membuat aturan seperti pedagangan serta aturan legal lainnya yang berhubungan antar negara.

Analisis Gramsci menjadi penting dalam wacana hegemoni yang berkembang saat ini. Gramsci berusaha melakukan analisis terhadap struktur ekonomi, politik, dan ideologi. Gramsci melakukan studi tentang konsekuensi reformasi ekonomi neolibral dan fokus dengan mensyaratkan kekuatan sebagai pemegang struktur ekonomi dan hubungan antar kelas. Hegemoni dalam sudut pandang Gramsci adalah sebuah usaha untuk menguasai suatu

10 Menurut data PBB awal 2017, jumlah korban jiwa di Yaman mencapai 10.000 namun ini adalah perkiraan terendah (kemungkinan besar angka sebenarnya jauh lebih tinggi). https://www.theguardian.com/world/2017/jan/16/yemen-war-death-toll-has-reached10000-un-says [9/3/2017]

11 The Guardian. 2016. "British-US Military in Command Room Saudi Strikes Yemen". Melalui $<$ https://www.theguardian.com/world/2016/jan/15/british-us-military-in-commandroom-saudi-strikes-yemen> [9/9/2016]

12 Comor, Edward A. 2008. Consumtion and the Globalization Project:International Hegemony and the Annihilation of Time, New York: Palgrave Macmillan. (20). 
negara melalui struktur ekonomi dan politik. Dengan representasi negara kuat dan membentuk aliansi negara, maka dominasi negara maju akan terjadi. ${ }^{13}$

Menurut Mearsheimer perilaku negara-negara terbentuk oleh struktur anarki internasional. Sistem anarki memaksa negara-negara untuk bersaing demi kekuatan hingga negara-negara berupaya mencari hegemoni dan lebih agresif. Tujuan suatu negara seperti Amerika Serikat adalah untuk mendominasi seluruh sistem, karena dengan cara itu ia dapat meyakinkan bahwa tidak ada negara lain atau gabungan negara yang bahkan akan berpikir untuk berperang melawan Amerika Serikat. ${ }^{14}$

Pada akhir Perang Dunia II, Amerika Serikat merupakan kekuatan utama dalam ekonomi politik dunia. Produktivitas di bidang manufaktur dan kontrol atas pasar dan bahan baku membuat AS mendominasi pemasokan barang (ekspor) internasional. Secara spesifik, penguasaan Amerika Serikat terhadap perekonomian internasional disebabkan oleh beberapa hal berikut ini ${ }^{15}$ :

1. Membangun sistem keuangan internasional yang stabil, didesain untuk memfasilitasi perdaganagan bebas internasional dan pembayaran. Hal ini membuat Amerika Serikat mampu mengatur sistem moneter serta menyediakan likuiditas internasional yang cukup.

2. Menyediakan pasar terbuka bagi barang. Amerika Serikat dengan aktif bekerja untuk mengurangi tarif dan menjadi pemimpin dalam menekan penghapusan tersebut walaupun masih mentolerir diskriminasi regional.

3. Menyediakan akses minyak dengan harga stabil. Perusahaanperusahaan Amerika Serikat menyediakan minyak bagi Eropa dan Jepang dari Timur Tengah.

Oleh sebab itu, hegemoni Amerika Serikat dalam politik minyak dilakukan dengan membangun hubungan politik yang erat dengan kerajaan Arab Saudi

13 Roccu, Roberto. 2013. The Political Economy of the Egyptian Revolution: Mubarak Economic Reforms and Failed Hegemony. New York: Palgrave Macmillan. (18)

14 Jackson, Robert dan George Sorensen. 2013. Pengantar Studi Hubungan Internasional: Teori dan Pendekatan, Pentj. Dadan Suryadipura. Yogyakarta: Pustaka Pelajar (145-146).

15 Keohane, Robert O. 1984. After Hegemony: Cooperation and Discord in The World Political Economy. New Jersey: Princeton University Press. (138-139). 
dan superioritas Amerika Serikat dalam politik dan ekonomi menjadi cara untuk ikut campur tangan dalam politik domestik di Timur Tengah.

\section{Hubungan antara Amerika Serikat-Arab Saudi}

Hubungan Amerika Serikat-Arab Saudi secara historis berpijak dari kerjasama dalam bidang perminyakan. Kerjasama ini sekaligus menandai transformasi masing-masing negara. Sumber minyak melimpah secara cepat mengubah wajah Arab Suadi mejadi negara maju dengan pembangunan infrastruktur luar biasa, sedangkan Amerika Serikat melanggengkan dominasi sebagai puncak penguasa dunia.

Bukan hanya itu, kedua negara kemudian membangun kerjasama dalam bidang lainnya seperti keamanan nasional mulai dari 1950 hingga saat ini. ${ }^{16}$ Hubungan di antara kedua negara sempat memanas akibat isu-isu regional, terutama perbedaan pendangan terhadap konflik Arab-Israel pada tahun 1948, 1967 dan 197317, namun para presiden AS masa itu, seperti Truman, Eisenhower, Kennedy, Johnsen, dan Nixon tetap memandang Arab Saudi sebagai sekutu terkuat dalam membendung penyebaran komunisme di kawasan Teluk. ${ }^{18}$

Hubungan khusus Amerika Serikat-Arab Saudi memungkinkan aksesakses informasi sensitifterhadap Amerika Serikat. Amerika Serikat membangun kantor khusus bagi kepentingan Arab Saudi, seperti Department Inside Treasury yang khusus menyiapkan berbagai macam akomodasi kebutuhan Arab Saudi dan menjadi satu-satunya kantor yang didirikan di negara asing. ${ }^{19}$

16 Pada tahun 1953 dibentuk Military Training Mission in Saudi Arabia (USMTM) dan lembaga ini menjadi fokus hubungan militer Amerika Serikat dengan Arab Saudi. Departemen Keamanan Amerika Serikat bekerjasama dengan para anggota Pertahanan dan Penerbangan (MODA) dan angkatan bersenjata Arab Saudi di bidang pengembangan peralatan, rencana, organisasi, prosedur administrasi, dan pelatihan militer.

17 Pada tahun 1948 merupakan pertempuran pertama antara Arab-Israel setelah diproklamirkannya Israel pada bulan 14 Mei 1948. Saat itu, tentara Arab dari Mesir, Transjordania (Jordan, Irak, Suriah dan Lebanon) menguasai beberapa area di wilayah selatan dan timur Palestina. Ambisi Israel untuk menguasai Yerusalem dan mengontrol jalan utama ke Yerussalem melalui Judeea menyebabkan meletusnya konflik berkepanjangan antara Arab dan Israel.

18 Ibid, 3-5.

19 Delaney, Jennifer S. "The Unlikely Partnership: The State of the U.S-Saudi Relationship". Melalui https://.hpu.edu/CHSS/History/GraduateDegree/MADMSTheses/files/Jennifer_ Delaney_Final_MADMS.pdf. 
Pasca Perang Dingin dan keberhasilan Blok Barat dalam membendung menyebarnya paham komunis, kedua negara ini semakin mempererat hubungan bilateral terutama dalam isu-isu keamanan masing-masing negara, mencegah konflik politik yang terjadi di wilayah Teluk Persia serta mencegah berbagai macam hambatan pasokan minyak Arab Saudi ke pasar internasional. Setelah terjadinya peristiwa 9/11 kedua negara ini kemudian membahas kerjasama dalam hal kontra terorisme dan bersama-sama memerangi fundamentalisme, terutama terkait keterlibatan Osama Bin Laden dan jaringan Al-Qaida dalam berbagai aksi terorisme. ${ }^{20}$ Bergabungnya Arab Saudi dengan AS dalam Perang Melawan Terorisme juga terkait dengan kepentingan keamanan nasional Saudi sendiri, karena warganya yang pernah mengikuti kamp-kamp pelatihan Al Qaida di Afghanistan telah kembali ke Arab Saudi sekitar tahun 2003, kemudian membentuk organisasi ekstrim di Semenanjung Arab. Organisasi ini kemudian dikenal dengan nama Al-Qaida in the Arabian Peninsula (AQAP) dan mereka bekerjasama dengan sekutu lokal di berbagai kawasan. Sejak bulan Mei 2003 hingga Juni 2004, Arab Saudi menghadapi berbagai serangan yang terorganisir dari jaringan terlatih AQAP, antara lain berbagai kasus penyerangan terhadap fasilitas-fasilitas pemerintahan di al-Khobar.

Level kerjasama antara Arab Saudi dan Amerika Serikat mengalami dinamika, sebagai berikut. Dalam beberapa isu, Arab Saudi dan AS bekerja sama, misalnya dalam melawan Uni Soviet dan menghadapi krisis di Irak dan Yaman. Keduanya mendukung Irak dalam menghadapi Iran selama era Perang Iran-Irak. Namun kemudian keduanya berkoalisi dalam melawan Saddam Hussein yang menginvasi Kuwait pada 1990-an. Di satu sisi Saudi sangat bergantung kepada AS untuk suplai senjata dan pelatihan militer. Saudi memiliki misi penasihat militer AS di dalam struktur militer regulernya, di Dewan Pertahanan Nasional (National Guard), dan pasukan anti-teror di Kementerian Dalam Negeri. Namun dalam hal isu Palestina, keduanya beberapa kali berselisih pendapat. Misalnya pada masa konflik Arab-Israel dan era embargo minyak 1973. Saudi juga pernah menentang AS terkait perjanjian Camp David antara Mesir dan Israel yang dimediasi AS; menentang agresi AS ke Irak pada 2003 pada awalnya, namun kemudian mengizinkan

20 Lippman, Thomas W. 2004. Inside the Mirage American's Fragile Partnership with Saudi Arabia. United State of America: Westview Press.(327). 
AS menggunakan wilayah udaranya untuk dilalui pesawat AS. Saudi juga mengkritik AS yang dipandangnya tidak tegas terhadap Suriah serta menjalin perjanjian nuklir dengan Iran. ${ }^{21}$

Jenis kerjasama Amerika Serikat dan Arab Saudi secara umum terbagi dalam dua jenis:

\section{Kerjasama di Bidang Strategis}

Meskipun dalam beberapa isu terdapat perbedaan pendapat di antara kedua negara, kerjasama di antara kedua negara cukup kuat khususnya pada isuisu kontra-terorisme, pendidikan, perdagangan, dan keamanan energi.

Kerjasama bidang energi sangat terkait dengan posisi AS sebagai negara adidaya. Pasca Perang Dunia II pada tahun 1945, Amerika Serikat dan Uni Soviet segera terlibat konflik baru, yaitu perebutan supremasi kekuasaan global. Menyadari bahwa Timur Tengah sebagai produsen minyak terbesar amat dibutuhkan dalam Perang Dingin, terlebih demi menggerakkan roda industri militer, Amerika Serikat sangat memberikan perhatian khusus dalam peningkatan hubungannya dengan Arab Saudi.

Secara historis kerjasama antara kedua belah pihak terjalin melalui industri minyak. Hubungan ini dibangun sejak era Raja Abdulaziz dan kerjasama ini membuat industri minyak Arab Saudi semakin maju. Kerjasama AS-Saudi di bidang minyak berupa eksplorasi, ekspansi, dan inventasi dari perusahaan minyak Amerika Serikat serta pembentukan ARAMCO.

Pada tahun 1945, Presiden AS, Frankin D. Roosevelt bertemu dengan Raja Abdulaziz membahas kerjasama kedua negara terkait dengan minyak dan isu Israel dan Palestina. Sejak saat itu, Riyadh dikenal sebagai sekutu dekat Washington di Timur Tengah. ${ }^{22}$

21 Cordesman, Anthony H. 2016. "Saudi Arabia and the United States: Common Interests and Continuing Sources of Tension" . melalui https://csis-prod.s3.amazonaws.com/s3fspublic/legacy_files/files/publication/160229_Cordesman_Saudi_Arabia.pdf

22 Council on Foreign Relations. 2015. "US-Saudi Relations". Melalui https://www. files.ethz.ch/isn/190644/U.Ssaudi.pdf. [1/4/2017] 
Sebagai hasilnya, Arab Saudi menyediakan akses khusus terhadap suplai minyak kepada Amerika Serikat dan Amerika Serikat membantu Arab Saudi dalam bidang militer dan menjamin keamanan negara. ${ }^{23}$

Hampir lebih dari 80 tahun hubungan dipomatik Amerika Serikat dan Arab Saudi dalam bidang korporasi energi dan bisnis terjalin dengan intens. Amerika Serikat secara terus-menerus menyediakan produk teknologi tinggi bagi kepentingan perkembangan industri Arab Saudi. Pada tahun 2013, ekspor dari Amerika Serikat ke negara-negara Arab mencapai rekor dengan nilai lebih dari 70 miliar Dollar dan 19 miliar Dollar di antaranya mengalir ke Arab Saudi.

Di bidang bisnis, kedua negara membentuk Dewan Bisnis Amerika-Arab Saudi (USSABC) sejak tahun 1993 yang merupakan organisasi non profit yang diinisiasi oleh Kementerian Keuangan kedua negara. Lembaga ini menyediakan akses dan jaringan bisnis, melalui misi-mis perdagangan dan pusat pengembangan bisnis, dan kini beranggotakan 400 perusahaan terkemuka. ${ }^{24}$

\section{Kerjasama di Bidang Kontra-Terorisme}

AS dan Arab Saudi memiliki kerjasama yang panjang dalam melawan terorisme. Hal ini dilaporkan dalam laporan tahunan Departemen Dalam Negeri AS. Terlepas dari fakta bahwa orang-orang Saudi terlibat dalam serangan terror 9/11, Saudi diberitakan telah melakukan tindakan tegas kepada kelompok-kelompok ekstrim di dalam negeri, yang akhirnya membuat Osama Bin Laden keluar dari Saudi, pindah ke Yaman, dan akhirnya ke Afghanistan hingga akhirnya tewas dalam serangan anti-teror AS. ${ }^{25}$ Pada Mei 2017, Arab Saudi menggelar Arab-Islamic American Summit yang dihadiri sekitar 50 pemimpin negara-negara Muslim. Raja Salman menyatakan bahwa KTT ini memperkuat aliansi melawan ekstrimisme dan terorisme. ${ }^{26}$

23 Samuel Plank. 2016. "Reevaluating the U.S-Saudi Partenship" Melalui <http:// harvardpolitics.com/world/reevaluating-u-s-saudi-partnership $>$. [4/4/2017]

24 U.S.-Saudi Arabian Business Council. 2015. Melalui <http://www.us-sabc.org/i4a/ pages/Index.cfm?page>. [2/10/2016]

25 Cordesman, Anthony H. 2016. "Saudi Arabia and the United States: Common Interests and Continuing Sources of Tension" . melalui https://csis-prod.s3.amazonaws.com/s3fspublic/legacy_files/files/publication/160229_Cordesman_Saudi_Arabia.pdf [1/6/2017]

26 Al Arabiya.2017."Defeating terror key message of Arab Islamic American Summit". Melalui http://english.alarabiya.net/en/News/gulf/2017/05/21/Saudi-King-Salman-tweetsahead-of-Arab-Islamic-American-Summit-.html [1/6/2017] 


\section{Sejarah Singkat Konflik Yaman}

Meskipun situasi di Yaman mulai bergolak seiring dengan gelombang Arab Spring 2011, ketidakstabilan politik di negara ini sudah terjadi jauh sebelumnya. Republik Yaman merupakan unifikasi antara Republik Arab Yaman (RAY) yang berada di wilayah utara Yaman dengan Republik Demokratik Yaman (RDY) yang berada di selatan Yaman. Setelah terjadi berbagai perang antara RAY dan RDY selama bertahun-tahun, pada awal 1980-an ditemukan sumber minyak di perbatasan kedua negara tersebut yang memunculkan kesadaran mengenai kesamaan kepentingan di antara keduanya. Pada bulan Mei 1988, pemerintah kedua negara sepakat untuk meredakan ketegangan dan membangun kerjasama eksplorasi minyak di perbatasan, serta membentuk Yemeni Company for Investment in Mineral and Oil Resources (YCIMOR). Eksplorasi minyak dilakukan bersama dengan perusahaan AS, Exxon dan Hunt Oil Company.

Akhirnya pada tanggal 22 Mei 1990 dideklarasikan penggabungan kedua Negara, dengan nama Republik Yaman. Ali Abdullah Saleh yang semula adalah Presiden RAY ditetapkan menjadi presiden, sementara Ali Salim Beidh dari RDY menjadi perdana menteri. Parlemen gabungan juga dibentu dengan 301 kursi yang terdiri dari 159 anggota dari ex-RAY dan 111 anggota dari ex-RDY, serta 31 anggota independen. Sejak awal berdirinya Ali Abdullah Saleh dan partainya, General People Congress, sangat dominan. Meskipun terdapat partai oposisi di parlemen, namun sebelum era Arab Spring, tidak ada tantangan berarti bagi kepemimpinan Saleh. ${ }^{27}$

Meskipun secara de jure, sistem politik negara ini menerapkan sistem multipartai dengan kebebasan menyampaikan aspirasi, persamaan di depan hukum dan independensi pengadilan hukum, dari sisi ekonomi, tidak banyak kemajuan ekonomi yang dicapai Yaman pasca unifikasi. Negara ini merupakan negara termiskin di Timur Tengah dengan GDP perkapita tahun 2011 sebesar 1113,1 US Dollar dan semakin anjlok pada tahun 2016, yaitu 774,5 US Dollar. ${ }^{28}$

27 Durac ,Vincent. 2012. Yemen's Arab Spring-Democratic Opening oor Regime Maintenance, BRISMES Annual Conference. (4)

28 Trading Economics. 2017. "Yemen GDP per capita". Melalui https://tradingeconomics. com/yemen/gdp-per-capita [1/1/2017] 
Seiring dengan gejolak Arab Spring di berbagai Negara Arab, sejak awal Februari 2011 kelompok-kelompok oposisi Yaman pun mengadakan berbagai aksi demonstrasi menuntut lengsernya Saleh yang telah berkuasa sekitar 30 tahun dan dinilai melakukan korupsi dan pelanggaran HAM. Saleh merespon dengan melakukan berbagai upaya reformasi, antara lain menjanjikan tidak akan lagi ikut pemilu presiden tahun 2013 dan melakukan amandemen UUD. Namun aksi protes terus berlanjut dan akhirnya pada 23 April 2011, Saleh bersedia mundur dari jabatannya dengan jaminan keselamatan. Namun janji mundur itu tidak ditepati dan pada Juni 2011 terjadi aksi pengeboman yang membuat Saleh terluka parah dan dirawat di Arab Saudi. Pada bulan September, Saleh kembali ke Yaman dan berusaha meredam konflik, namun menemukan jalan buntu berkepanjangan.

Akhirnya, pada bulan April 2011, Dewan Kerjasama Teluk (GCC) yang dipimpin oleh Arab Saudi dan didukung oleh Amerika Serikat dan Uni Eropa telah mendorong Ali Abdullah Saleh agar mundur dan mengusulkan kerangka transisi kekuasaan. Kesepakatan itu dinegosiasikan dengan kekuatan-kekuatan internal Yaman seperti kelompok Ali Muhsin dan The Ahmar Brothers, namun mengabaikan kelompok Houthi dan Hirak.

Akibatnya, kelompok Houthi dan Hirak menolak kesepakatan GCC dan memboikot pemilu pada tahun 2012. Kedua kelompok ini, mengklaim bahwa perjanjian transisi kepemimpinan Ali Abdullah Saleh yang digantikan Abdrabu Mansur Al Hadi hanya melanggengkan politik dominasi Yaman utara. Momentum ini menjadi pertanda buruk bagi stabilitas negara karena belum ada kesepakatan antara kelompok-kelompok yang mendukung Yaman Utara serta kelompok sipil pro-Yaman Selatan serta ketidaksiapan mereka telibat dalam proses politik yang baru lahir. ${ }^{29}$ Ketidakpastian politik pada proses transisi kepemimpinan di Yaman, dijadikan momentum oleh kelompok radikal Al Qaida (AQAP) untuk memperluas wilayah kekuasaannya di wilayah selatan. Kelompok Houthi di wilayah utara juga ingin menguasai politik secara penuh. Hingga pada akhirnya terjadi pertempuran antara kelompok Houthi dengan

29 Rozsa, Erzsebet N. The Arab Spring, Its Impact on the Region and on the Middle East Conference, Academic Peace Orchestra Middle East. (9) 
pihak pemerintahan di tepi kota Sanaa. Kondisi Sanaa yang semakin mencekam membuat Presiden Abdrabu Mansur Al Hadi memindahkan ibukota negara ke Aden. Namun akhirnya, Al Hadi memilih untuk meninggalkan Yaman, meminta perlindungan ke Arab Saudi pada 25 Maret 2015. Pada hari yang sama, Arab Saudi pun mulai membombardir Yaman.

Hingga saat artikel ini ditulis, Arab Saudi dan kelompok Houthi masih terlibat pertempuran sengit, selain dengan kedua kelompok ini, mereka juga masih berkonflik dengan kelompok cabang Al-Qaida (AQAP). Kelompok Houthi masih menjadi penguasa tidak resmi atas Provinsi Sa'adah dan sekitarnya. Fasilitas-fasilitas pemerintahan dan pos-pos militer setempat kini dikendalikan oleh para anggota Houthi. Beberapa wilayah di utara Yaman juga dikuasai kelompok ini, terutama karena mendapatkan dukungan dari pasukan Yaman yang masih loyal dengan mantan Presiden Ali Abdullah Saleh. Pada November 2016, Houthi dan sekutu politik mereka telah membentuk pemerintahan baru. Pembentukan pemerintahan baru yang diumumkan oleh Dewan Tinggi Politik Yaman ini telah memberikan pukulan bagi aliansi Arab Saudi yang selama 20 bulan terus membombardir Yaman karena hal itu bermakna bahwa warga Yaman masih terus tegak mempertahankan negara mereka dari agresi asing.

Dalam pengumuman Dewan Tinggi Politik Yaman disebutkan bahwa pemerintahan yang baru dibentuk ini ditugasi mengendalikan situasi dalam negeri dan melakukan konsolidasi dalam menghadapi agresi militer asing. ${ }^{30}$

Konflik Yaman kontemporer yang dimulai sejak agresi Arab Saudi 2015 secara garis besar melibatkan 3 kekuatan besar di dalam negeri, yaitu kelompok Houthi, kelompok pro-Abdrabu Al Hadi, dan kelompok AQAP (Al-Qaida in Arabian Peninsula). Sedangkan, secara eksternal yang terlibat langsung dalam konflik ini adalah koalisi Arab Saudi yang meliputi Mesir, Oman, Qatar, Uni Emirat Arab, serta 21 negara lainnya.

Berdasarkan data Januari 2017 Yaman terfragmentasi menjadi tiga entitas politik, sebagaimana dapat dilihat dalam peta berikut ini. Wilayah

30 Al-Jazeera. 2016. "Yemen Houthi Rebels Form Government". Melalui <http://www. aljazeera.com/news/2016/11/yemen-houthi-rebels-form-government>. [20/4/2017]. 
pertama (1) adalah wilayah yang dikuasai oleh kelompok Houthi. Ini adalah wilayah-wilayah yang sangat strategis, terutama Sanaa yang merupakan pusat perekonomian Yaman dan wilayah utara yang merupakan produsen minyak dan gas. Di beberapa titik, kelompok Houthi menguasai basis militer pemerintah Yaman. Wilayah kedua (2) dikuasai loyalis Abdrabu Al Hadi yang mendapat dukungan kuat dari Arab Saudi. Sedangkan wilayah ketiga (3) adalah teritorial AQAP yang lebih banyak berupa pegunungan dan wilayah kering di selatan Yaman.

\section{Kepentingan Ekonomi Politik AS-Arab Saudi dalam Konflik Yaman}

Dari perspektif hukum internasional, perang yang dipimpin Arab terhadap

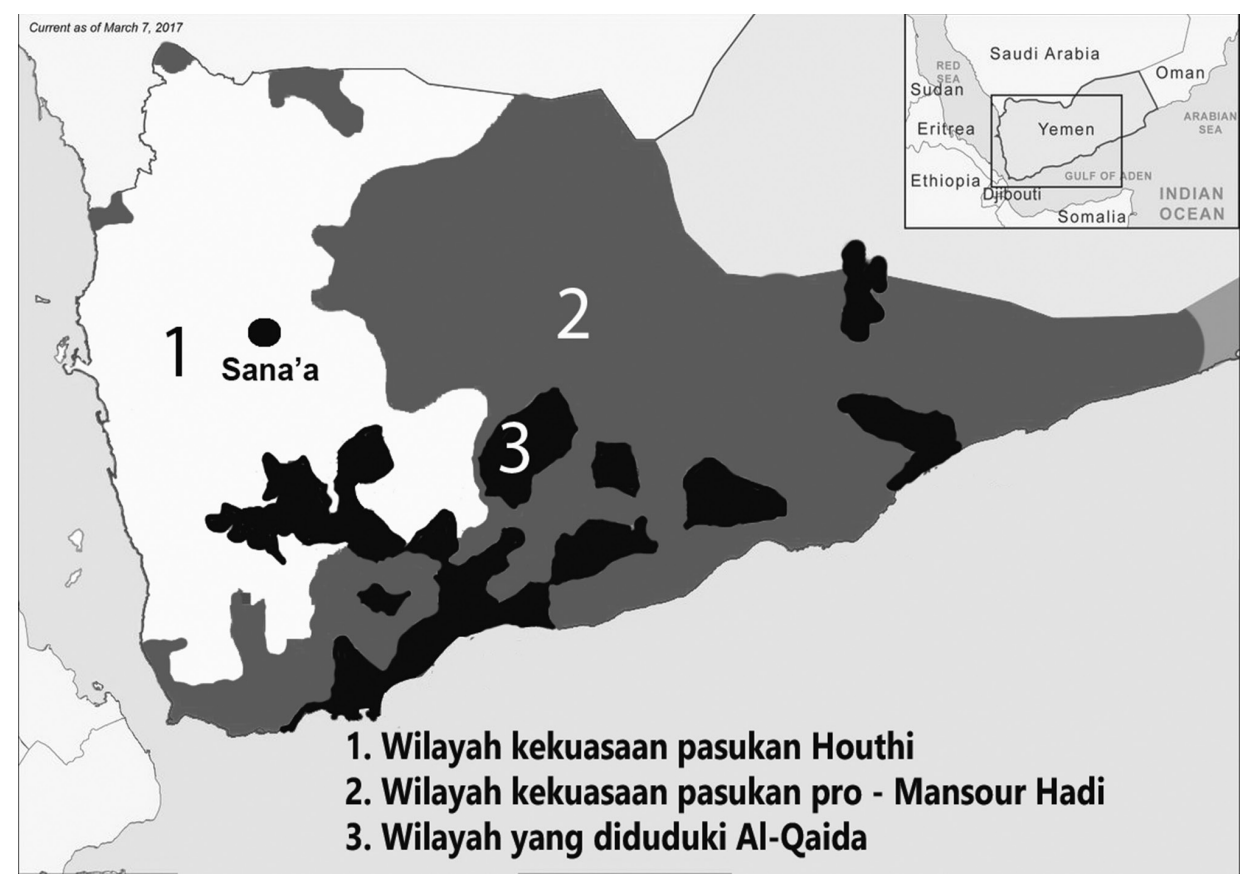

Sumber peta: www.criticalthreats.org

Yaman adalah tindak kriminal. Serangan militer ke Yaman tidak mendapatkan izin dari Dewan Keamanan PBB dan melanggar Pasal 51 dari Piagam PBB.

Pasal 51 berbunyi sebagai berikut:

"Tidak ada suatu ketentuan dalam Piagam ini yang boleh merugikan hak perseorangan atau bersama untuk membela diri apabila suatu serangan 
bersenjata terjadi terhadap suatu anggota Perserikatan BangsaBangsa, sampai Dewan Keamanan mengambil tindakan-tindakan yang diperlukan untuk memelihara perdamaian serta keamanan internasional. Tindakan-tindakan yang diambil oleh anggota-anggota dalam melaksanakan hak membela diri ini harus segera dilaporkan pada Dewan Keamanan dan dengan cara bagaimanapun tidak dapat mengurangi kekuasaan dan tanggung jawab Dewan Keamanan menurut Piagam ini untuk pada setiap waktu mengambil tindakan yang dianggap perlu untuk memelihara atau memulihkan perdamaian serta keamanan internasional"

Dalam Pasal 51 ini terkandung prinsip bahwa sebuah negara tidak dapat memerangi negara lain meskipun dalam rangka membela diri sebelum mendapatkan izin dari Dewan Keamanan PBB. Atau dengan kata lain, sebuah negara bisa saja memerangi negara lain yang telah mengancam keselamatannya, sepanjang telah berkoordinasi dengan Dewan Keamanan PBB. Faktanya, gerakan bersenjata di Yaman tidak menimbulkan ancaman perang ke Riyadh dan tidak berniat memicu perang di semenanjung Arab. Konflik Yaman adalah konflik internal yang seharusnya tidak diintervensi oleh pihak asing. Gelombang demonstrasi rakyat Yaman yang akhirnya menjadi konflik bersenjata adalah dalam rangka menuntut reformasi dan perbaikan kondisi dalam negeri, bukan gerakan memerangi negara lain, termasuk Arab Saudi.

Anthony Cordesman (2015) dalam paper yang dirilis Center for Strategic and International Studies menyatakan bahwa :

"Yemen is of major strategic importance to the United States, as is the broader stability of Saudi Arabia all of the Arab Gulf states. For all of the talk of US energy 'independence,' the reality remains very different. The increase in petroleum and alternative fuels outside the Gulf has not changed its vital strategic importance to the global and US economy ... Yemen does not match the strategic importance of the Gulf, but it is still of great strategic importance to the stability of Saudi Arabia and the Arabian Peninsula.... Yemen's territory and islands play a critical role in 
the security of another global chokepoint at the southeastern end of the Red Sea called the Bab el-Mandab or 'gate of tears."'11

Bagi AS, Yaman memiliki nilai penting dan strategis, meskipun tidak atau belum menyamai nilai strategis negara-negara Teluk. Kepentingan AS terhadap Yaman ada dua, yaitu (1) demi menjaga kestabilan Arab Saudi dan Semenanjung Arab, dan (2) menjaga kestabilan Bab el-Mandab. Dengan demikian, ada kesamaan kepentingan antara Arab Saudi dan AS, yaitu keduanya memandang bahwa kestabilan politik di Yaman sangat berpengaruh bagi kestabilan Arab Saudi. Karena Arab Saudi adalah partner penting bagi AS, AS pun berkepentingan dengan kestabilan politik di Yaman. Keduanya sama-sama menghendaki adanya pemerintahan yang bersahabat dengan mereka, dan kelompok Houthi tidak menjadi pilihan mereka. Selain itu, Bab el-Mandab adalah jalur sempit yang menjadi penghubung strategis antara Laut Mediterrania dan Laut Hindia, yang dilewati oleh kapal-kapal yang mengangkut berbagai komoditi ekspor dari Teluk Persia menuju terusan Suez dan jalur minyak Suez-Mediterranean (SUMED). AS mengkhawatirkan bahwa kekuatan Houthi akan mengancam jalur penting ini sehingga transportasi ekspor terganggu. ${ }^{32}$

Dari sisi ekonomi-politik, Yaman memiliki sumber daya alam yang sangat kaya, terutama minyak dan gas alam. Kekayaan alam Yaman masuk dalam kategori kekayaan luar biasa, dengan memiliki 50 kilang minyak produktif dengan kualitas minyak bumi standar dunia, ditambah pula dengan cadangan gas alamnya yang mencapai 19 triliun kaki kubik. Yaman juga memiliki cadangan tambang emas yang cukup besar dan tercatat sebagai negara Arab produsen emas ke-6 dunia.

Pakar ekonomi asal Yaman, Hassan Ali Al Sanaeri mengungkapkan aspek kepentingan ekonomi AS dan Arab Saudi terkait Yaman. Menurutnya, kedua negara telah menandatangani perjanjian rahasia yang isinya menghalangi Yaman untuk mengeksplorasi cadangan minyaknya selama 30 tahun terakhir. Padahal cadangan minyak Yaman sangat besar, terutama di kawasan Ma'rib,

31 Cordesman, Anthony H.2015. «America, Saudi Arabia, and the Strategic Importance of Yemen». Melaluihttps://www.csis.org/analysis/america-saudi-arabia-and-strategicimportance-yemen [2/6/2017] 
al-Jawf, Shabwah dan Hadhramaut. Al Sanaeri juga mengutip dokumen rahasia yang diungkap oleh Wikileaks mengenai adanya komite khusus yang dipimpin mantan Menteri Pertahanan Saudi, Sultan bin Abdul Aziz, yang bertanggung jawab dalam proyek penggalian kanal dari Arab Saudi ke Laut Arab, via sehingga jalur Hormuz dan Bab al-Mandab tidak lagi signifikan. ${ }^{33}$ Bila proyek ini berhasil, konstelasi geopolitik di kawasan akan berubah karena ketergantungan dunia kepada Selat Hormuz yang berada di bawah kontrol Iran akan berkurang dan di saat yang sama, posisi tawar-menawar politik Iran pun melemah.

Kabel diplomatik AS yang dibocorkan oleh Wikileaks, ditulis oleh Duta Besar AS, Stephen A. Seche, yang di antaranya mengkonfirmasi tentang cadangan minyak Yaman.

"In an October 13 meeting with Econoff, the Chair of the Petroleum Exporting and Production Authority (PEPA), Ahmed Abdillah, told Econoff that the governorates of Shabwa, Marib and al-Jawf have high potential for significant gas deposits. He said that natural gas deposits have been found in Occidental Block 20 (Marib-al-Jawf), Occidental Block S-1 (Shabwa) and Canadian Nexen Block 51 (Hadhramout). ${ }^{134}$

Laporan dari USGS tahun 2002 juga telah menyebutkan adalah cadangan minyak yang sangat besar di Yaman..$^{35}$ Dalam laporan mengenai Pulau Samhah di Teluk Aden, disebutkan bahwa pulau itu mengandung cadang minyak di sela-sela bebatuannya. Militer AS sudah menguasai pulai ini dan telah pula membangun pangkalan militer terbesar di kawasan, yaitu di Pulau Socotra, tak jauh dari Pulau Samhah. Selain itu, cadangan minya juga ditemukan di dasar Laut Merah yang membentang dari Laut Merah hingga Yaman hingga ke

33 Farsnews.2016. «Economic Expert Discloses US-Saudi Arabia Agreement on Yemenss Oil Reserves». Melalui <http://en.farsnews.com/newstext. aspx?nn=13950921001287>

34 Wikileaks. 2008. «Public Library of US Diplomacy». Melalui https://wikileaks.org/ plusd/cables/08SANAA1923_a.html [1/6/2017]

35 Ahlbrandt, Thomas S. 2002. «Madbi Amran/Qishn Total Petroleum System of the Ma'Rib - Al Jawf/Shabwah, and Masila-Jeza Basins, Yemen». Melalui https://pubs. usgs.gov/bul/b2202-g/b2202-g.pdf [1/6/2017] 
pantai Arab Saudi, Sudan, dan Eritrea. Semua kekayaan alam ini jelas menjadi factor utama keterlibatan AS di kawasan. ${ }^{36}$

Pernyataan Al Sanaeri sesuai dengan pemaparan Joke Buringa, staf ahli TimurTengah di Kementerian Luar Negeri Belanda. Dalam artikelnya ia menulis bahwa selama ini AS selalu menekan negara-negara Teluk agar membangun jalur alternatif pipa migas. Hal ini ditindaklanjuti oleh Saudi, Bahrain, Uni Emirat Arab, Oman, dan Yaman dengan rancangan pembangunan TransArabia Oil Pipeline pada tahun 2007. Jalur migas Abu Dhabi-Fujairah (UEA) merupakan realisasi proyek ini, namun dalam perkembangannya Oman justru menandatangani kerjasama pembangunan pipa migas dengan Iran. Pilihan yang paling menguntungkan Saudi dalam kondisi ini adalah pembangunan jalur pipa migas Saudi-Hadramaut. ${ }^{37}$

Dengan demikian dapat disimpulkan bahwa langkah yang terus-menerus membombardir Yaman, yang jelas memakan biaya yang sangat besar, berakar dari kepentingan ekonomi yang amat besar ini. Di satu sisi, cadangan minyak Arab Saudi diperkirakan akan habis dalam beberapa waktu ke depan sehingga penguasaan atas Yaman, atau keberadaan pemerintahan pro-Saudi di Yaman, merupakan kepentingan Arab Saudi. Di saat yang sama, AS juga sangat membutuhkan cadangan minyak sehingga dukungan AS terhadap agresi ke Yaman adalah bagian dari politik'keamanan energi' AS.

Hubungan AS-Yaman secara langsung sebenarnya telah terjalin lama. Sejak 2009, kedua negara menjalin kerjasama di bidang keamanan dan khususnya perang melawan terorisme, yang seiring dengan mengalirnya bantuan dana AS ke Yaman demi menstabilkan kondisi keamanan dan prekonomian Yaman. Pemerintah Ali Abdullah Saleh membutuhkan dukungan AS dalam melawan pemberontak Al-Houthi dan rongrongan AQAP. Pada tahun 2009 AS mengirimkan beberapa ahli militernya ke Yaman untuk memberikan pelatihan militer. Negeri Paman Sam ini juga mengalokasikan dana hingga 200 juta Dollar untuk pelatihan dan melengkapi peralatan militer Yaman. Dalam kunjungan Menteri Luar Negeri AS, Hillary Clinton, ditekankan bahwa AS telah menyepakati program bantuan di bidang ekonomi sejumlah

36 Butler, By Phil. 2016. "Yemen, A War for Profit, Saudi Genocide Backed by Obama". Melaluihttp://www.globalresearch.ca/yemen-a-war-for-profit-saudi-genocide-backedby-obama/5519856 [20/5/2017[

37 Wayback Machine. 2015. «Divide and Rule: Saudi Arabia, Oil and Yemen». Melalui http:// web.archive.org/web/20150701113930/http:/www.jokeburinga.com/divide-and-rulesaudi-arabia-oil-and-yemen-3/ [2/3/2017] 
300 juta Dollar. Bantuan tersebut untuk membantu Yaman mengatasi sumber daya minyak yang berkurang serta mengatasi kekurangan air yang sangat parah..$^{38}$ Pada tahun 2016 AS kembali menggelontorkan dana sekitar 327 juta Dollar bagi warga Yaman yang terkena dampak konflik. ${ }^{39}$

Pemberian dana terhadap Yaman, secara politis bertujuan untuk menguasai wilayah-wilayah strategis Yaman, dimana wilayah Yaman Selatan seperti pulau Socotra dimana menjadi basis pangkalan militer Amerika Serikat dengan tujuan patroli terhadap kapal-kepal tanker yang berlayar menuju Eropa. Selain itu, basis militer Amerika ini bertujuan untuk melakukan serangan terhadap basis-basis kekuatan AQAP terutama di wilayah Azzan, AlBayda dan Tarim.

Ketika sebagian rakyat Yaman yang dipelopori kelompok Houthi berhasil menumbangkan pemerintahan Abdrabu Al Hadi, kepentingan AS dan Saudi menjadi terganggu. Hal inilah yang mendasari dukungan AS terhadap Saudi dalam aksi invasi ke Yaman. Seperti dipaparkan oleh Menteri Luar Negeri Saudi, Adel al-Jubeir, militer AS (dan Inggris) berada di ruang komando serangan militer ke Yaman. "Ada pejabat Inggris dan AS dan negara-negara lain di ruang komando kami. Mereka mengetahui daftar target [pengeboman] dan mereka mengetahui apa yang kami lakukan dan apa yang tidak kami lakukan," kata Al Jubeir di London setelah bertemu dengan para menteri Inggris dan Menteri Luar Negeri AS, John Kerry. ${ }^{40}$

Pernyataan Al Jubeir menunjukkan bahwa Arab Saudi secara 'sukarela' berada di bawah pengaruh AS dalam aksi agresinya ke Yaman, dan pernyataan ini secara eksplisit menunjukkan adanya hegemoni AS terhadap Arab Saudi dalam serangan ke Yaman. Arab Saudi memandang bahwa serangan ke Yaman adalah demi kepentingan nasionalnya namun pada hakikatnya, ada pihak yang memiliki kepentingan ekonomi yang lebih besar, yaitu AS.

38 Apriyanus. 2016. «Intervensi Amerika Serikat Dalam Penanganan Pemberontakan AlHouthi di Tahun 2004-2014». ejournal Ilmu Hubungan Internasional, Vol, 4 No. 1: 302.

39 Mclaughlin, Elizabeth and Luis Martinez. 2015. "The US Role in Yemen: What You Need to Know". Melalui <http://abcnews.go.com/International/us-role-yemen/ story >. [2/3/2017]

40 Graham-Harrison, Emma. 2016. «British and US military in command room» for Saudi strikes on Yemen». Melalui < https://www.theguardian.com/world/2016/jan/15/britishus-military-in-command-room-saudi-strikes-yemen > [3/5/2017] 


\section{Kesimpulan}

Dalam artikel ini telah dipaparkan bahwa ada kepentingan ekonomi yang sangat besar di balik serangan Arab Saudi ke Yaman. Kepentingan ekonomi itu terkait dengan Arab Saudi yang ingin mendapatkan akses ke sumber-sumber minyak baru. Namun yang berkepentingan lebih besar adalah Amerika Serikat yang telah mengetahui bahwa cadangan minyak yang dimiliki Yaman sangat besar. Amerika Serikat sejak tahun 1940-an telah menjalin kerjasama erat dengan Arab Saudi dalam kerangan politik keamanan energinya, atau dengan kata lain, dalam upaya mengamankan suplai energi. Kehadiran pemerintahan yang bersahabat dengan Arab

Saudi dan Amerika Serikat adalah faktor penting dalam pengamanan suplai energi ini.

Namun dalam agresi ke Yaman, serangan dilakukan oleh militer Saudi sementara militer AS berada 'di ruang komando'. Penjelasan dalam artikel ini telah membuktikan bahwa terjadinya konflik di Yaman tidak dapat terlepas dari peran dan "campur tangan" Amerika Serikat, namun Arab Saudi menjadi "perpanjangan tangan" Amerika Serikat di Timur Tengah. Dengan demikian dapat disimpulkan bahwa kebijakan luar negeri Arab Saudi dihegemoni Amerika Serikat. 